\author{
dr Hanna KRUK \\ Wydział Przedsiębiorczości i Towaroznawstwa, Akademia Morska w Gdyni \\ e-mail: h.kruk@wpit.am.gdynia.pl
}

DOI: $10.15290 /$ ose.2017.04.88.13

\title{
WYBRANE METODY OCENY ZRÓWNOWAŻENIA GOSPODARKI LEŚNEJ
}

\begin{abstract}
Streszczenie
Założenia koncepcji trwałego i zrównoważonego rozwoju są wdrażane do różnych działów gospodarki, w tym do leśnictwa. Celem zrównoważonej gospodarki leśnej jest utrzymanie żywotności i potencjału produkcyjnego lasów w długim czasie, zachowanie ich bioróżnorodności oraz wszystkich funkcji pełnionych przez lasy, tj. : gospodarczych, ekologicznych i społecznych. Jednak konieczne jest monitowanie, czy przyjęte cele są osiagane, a zasady - przestrzegane. W związku z tym, stosuje się różne metody oceny zrównoważenia, najczęściej zestawy mierników. Celem artykułu jest analiza wybranych, powszechnie stosowanych systemów wskaźników oraz próba oceny stopnia zrównoważenia polskiego leśnictwa i zmian zachodzących w gospodarce leśnej.
\end{abstract}

Słowa kluczowe: rozwój zrównoważony, gospodarka leśna, mierniki

\section{SELECTED ASSESSMENT METHODS OF SUSTAINABLE FOREST MANAGEMENT}

\section{Summary}

The principles of sustainable development are implemented in many sectors of the economy, including forestry. The main aim of sustainable forest management (SFM) is to preserve the vitality of forests and their productive potential in the long term, maintain their biodiversity and all the functions: ecological, economic, and social ones. It is crucial to the process of sustainability that the assumed goals are achieved and that the principles are respected. In SFM, various methods of assessment are used, usually based on a system of indicators. The aim of the paper is to analyse selected, commonly used indicators and to estimate the level of sustainability in the Polish forestry and its changes in time.

Key words: sustainable development, forestry management, indicators

JEL classification: Q01, Q23, C10

\section{Wstęp}

Założenia dotyczące zrównoważonej gospodarki leśnej zostały sformułowane podczas Szczytu Ziemi w Rio de Janeiro w 1992 roku. Przyjęto wówczas, że lasy powinny być zarządzanie w sposób zrównoważony zarówno w odniesieniu do: pozyskania drewna, 
jak i pasz; żywności (np.: zwierzyna, grzyby, jagody) lub leków (roślin leczniczych); innych produktów leśnych, jak i lasów jako miejsca pracy, odpoczynku oraz lasów jako schronienia dla dzikiej przyrody i enklawy bioróżnorodności. Za istotną uznano także rolę lasów w pochłanianiu dwutlenku węgla. Lasy, zgodnie z tymi założeniami, powinny zaspokajać potrzeby: ekologiczne, ekonomiczne i społeczne, ale również kulturowe i duchowe. Podkreślono konieczność ochrony lasów przed: zanieczyszczeniami powodującymi ich degradację, chorobami drzew, szkodnikami oraz pożarami [Report of the United Nations...].

Podstawowe międzynarodowe założenia w zakresie prowadzenia gospodarki leśnej zostały sformułowane w dokumencie ONZ pt.: Zasady leśne (Forest principles). Przyjęto w nim, że poszczególne kraje maja prawo do eksploatowania swoich zasobów, zgodnie z przepisami prawa i przyjętymi założeniami rozwoju społeczno-gospodarczego, jednak powinny przy tym uwzględniać kwestie utrzymania równowagi ekologicznej ekosystemów leśnych i ochrony środowiska. Ponadto, władze państwa powinny stworzyć warunki do partycypacji społecznej w podejmowaniu decyzji dotyczących lasów i gospodarki nimi [Report of the United Nations...; Chmielewski, 2015, s. 120-121]. W 2017 roku ONZ przyjęła swój pierwszy Strategiczny Plan dla Lasów na lata 2017-2030, którego misja jest promowanie zrównoważonego zarządzania lasami i zadrzewieniami [UN Strategic plan for forests].

Unia Europejska również przyjęła konieczność prowadzenia zrównoważonej gospodarki leśnej. Pierwsze strategie dotyczące leśnictwa opracowano w latach dziewięćdziesiątych XX wieku. Warto tutaj zwrócić uwagę na kolejne konferencje związane z ochroną lasów w Europie ${ }^{1}$ oraz strategię na rzecz leśnictwa opublikowaną w 1998 roku. W 2013 roku przygotowano założenia Nowej strategii leśnej UE na rzecz lasów $i$ sektora leśnodrzemnego. Trzy zasady przewodnie tej strategii to: prowadzenie trwałej i zrównoważonej gospodarki leśnej przy założeniu wielofunkcyjnej roli lasów, optymalne wykorzystanie zasobów leśnych przyczyniające się do rozwoju obszarów wiejskich oraz odpowiedzialność za lasy w skali krajowej i globalnej [Opinia Europejskiego Komitetu...].

Jednak konieczne jest monitorowanie, czy przyjęte cele są osiagane, a zasady przestrzegane. W tym zakresie stosuje się różne systemy mierników umożliwiające określenie stopnia realizacji przyjętych założeń, co wiąże się ze stosowaniem różnorodnych metod oceny.

Celem artykułu jest analiza wybranych metod oceny zrównoważonej gospodarki leśnej oraz próba oceny stopnia jej zrównoważenia w przypadku polskich lasów.

\section{Trwała i zrównoważona gospodarka leśna w Polsce}

Gospodarka leśna, zgodnie z obowiazującą definicją zawartą w Ustawie o lasach, to: działalność leśna w zakeresie urzqdzania, ochrony $i$ zagospodarowania lasu, utraymania i powiekeszania zasobów i upraw lesnych, gospodarowania zwierzyna, posyskiwania - zuyjatkiem skupu-drewna, symicy, choinek, karpiny, kory, igliwia, zwiersyny oraz plodón runa leśnego, a takize sprzedaż tych produktón oraz, realizacje pozaprodukcyjnych funkecji lasu [Ustawa o lasach, art. 6.1, pkt. 1].

1 Pierwsza taka konferencja odbyła się w 1990 roku w Strasburgu, a ostatnia w 2015 roku w Madrycie. 
W polskim leśnictwie od lat dziewięćdziesiątych XX wieku coraz intensywniej zaczęto wdrażać założenia koncepcji rozwoju trwałego i zrównoważonego. W 1991 roku weszła w życie nowa Ustawa o lasach. Na mocy tej ustawy Dyrektor Generalny LP zatwierdził i wprowadził Zasady hodowli lasu stanowiące uściślenie i uszczegółowienie zasad gospodarki leśnej. W 1995 roku został przyjęty Krajowy Program Zwiększania Lesistości (KPZL), który ma być realizowany do roku 2020². W drugiej połowie lat dziewięćdziesiątych Dyrektor Generalny Lasów Państwowych (LP) wydał dwa zarządzenia (nr 11 z 1995 roku i nr 11A z 1999 roku) wprowadzające wytyczne dotyczace gospodarki leśnej opartej na podstawach ekologicznych, potocznie nazywane zarządzeniami o „ekologizacji” leśnictwa.

W 1997 roku Rada Ministrów przyjęła dokument Polityka leśna państwa, w którym między innymi założono, że nadržlnym celem polityki leśnej jest wy żnaczenie kompleksu driałań ksztattujacych stosunek czlowieka do lasu, zmierzajacych do zachowania w zmieniajacej sie rzeczywistości prayrodniczej i spoteczno-gospodarczej warunków do trwałej w nieograniczonej perspektywie czasowej wielofunk.cyjności lasów, ich wszechstronnej użyteczności i ochrony oraz roli w ksztattowaniu środowiska prayrodniczego zgodnie zobecnymi i przyszłymi oczekiwaniami społeczeństwa [Polityka leśna państwa, 1997, s. 8].

Zgodnie ustawą o lasach, trwała i zrównoważona gospodarka leśna to: driałalność zmierzajaca do uksztaltowania struktury lasów i ich wykorzystania w sposób i tempie zapewniajacym trwate zachowanie ich bogactwa biologicznego, wysokiej produkcyjności orazpotencjatu regeneracyjnego, żywotności i zdolności do wypelniania, teraz i w prayszłości, wszystkich ważnych ochronnych, gospodarczych $i$ socjalnych funkcji na poziomie lokalnym, narodowym i globalnym, bez szkody dla innych ekosystemów [Ustawa o lasach, art. 6.1, pkt. 1a)]. Definicja ta jest zgodna z definicja przyjętą w 1993 roku podczas II Ministerialnej Konferencji w Helsinkach na temat ochrony lasów w Europie, która dotyczyła między innymi ochrony bioróżnorodności lasów i zrównoważonej gospodarki leśnej33.

Trwała i zrównoważona gospodarka leśna w Polsce jest prowadzona na podstawie następujących założeń: zachowanie ekosystemów leśnych i dostarczanych przez nie funkcji środowiskowych; ochrona lasów, zwłaszcza tych o charakterze naturalnym; ochrona gleb i wód oraz obszarów narażonych na degradację lub o istotnym znaczeniu społeczno-kulturowym; a także produkcja drewna oraz innych surowców i produktów uzyskiwanych w ramach tzw. ubocznego użytkowania lasu [Ustawa o lasach, art. 7]. Istotną kwestią jest również odpowiednie zagospodarowanie lasów, tak aby mogły korzystać z niego wszystkie grupy interesariuszy, a mianowicie odpowiednia infrastruktura: edukacyjna, turystyczna, rekreacyjna, łowiecka itp.

Na rysunku 1. przedstawiono główne, wybrane aspekty związane ze zrównoważoną gospodarką leśną.

Program ten jest co kilka lat aktualizowany i modyfikowany.

Tą tematyką zajmowano się również podczas kolejnych konferencji, w tym: konferencji w 1998 roku w Lizbonie i w 2003 roku w Wiedniu. W ich trakcie podjęto także kwestię pomiaru zrównoważonej gospodarki leśnej. 
RYSUNEK 1.

\section{Wybrane aspekty trwałego i zrównoważonego leśnictwa}

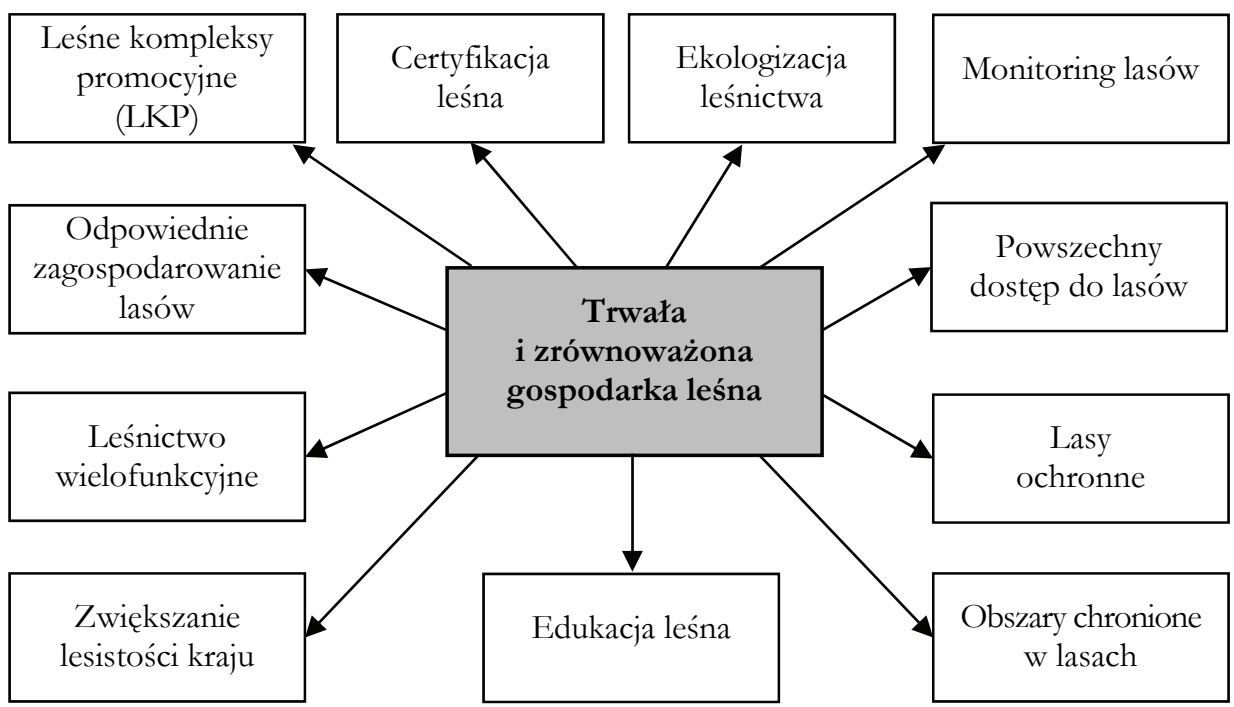

Źródło: opracowanie własne.

J. Chmielewski, analizując przepisy prawa związane z prowadzeniem gospodarki leśnej w Polsce, sformułował dziewięć zasad ogólnych dotyczących prawa leśnego. Są to zasady: trwałości utrzymania lasów, powiększania zasobów leśnych, jednolitej (niezależnej od form własności i osoby właściciela) gospodarki leśnej, powszechności ochrony lasów (zapewnienia ich prawidłowego funkcjonowania dzięki minimalizacji zagrożeń), powszechnego dostępu do lasów (w tym zbioru owoców runa) dla wszystkich obywateli ${ }^{4}$, ciagłości i zrównoważonego wykorzystania wszystkich funkcji lasów (produkcyjnych i pozaprodukcyjnych), kompleksowej ochrony środowiska leśnego, prewencji (zapobiegania negatywnemu oddziaływaniu na środowisko leśne) i planowości (sporządzania planów obejmujących gospodarkę leśną z uwzględnieniem zasad ochrony środowiska oraz rozwoju trwałego i zrównoważonego) [Chmielewski, 2015, s. 104-121].

Od pewnego czasu w koncepcji zrównoważonego leśnictwa coraz większą wagę przykłada się do prowadzenia wielofunkcyjnej ${ }^{5}$ gospodarki leśnej, która wiąże się z założeniem integralności funkcji pełnionych przez lasy. Wielofunkcyjna gospodarka wynika z konieczności brania pod uwage wszystkich naturalnych funkcji pełnionych przez lasy, ze szczególnym uwzględnieniem tych uznanych za wiodące. Wiąże się ona również z włączaniem społeczności lokalnej w procesy decyzyjne. Przy prowadzeniu takiej

$4 \quad$ Wyjątkiem od tej zasady w lasach publicznych jest np. zakaz wstępu na tereny upraw leśnych. Może także być wprowadzony czasowy zakaz wstępu do lasów w przypadku występowania zagrożenia pożarowego. Zgodnie z prawem, zakaz wstępu mogą wprowadzić prywatni właściciele lasu.

5 Ten model gospodarki jest w opozycji do prowadzonej wcześniej gospodarki leśnej opartej na funkcjach produkcyjnych, czyli tzw. gospodarki surowcowej. 
gospodarki należy więc uwzględnić funkcje: ekologiczne, ochronne, gospodarcze i społeczne (potrzeby różnych grup interesariuszy) [Kant, Berry, 2005, s. 8-9; Paschalis-Jakubowicz, 2011, s. 104-105; Płotkowski, 2010, s. 118-119; Zasady hodowli lasu, 2012]. Niektórzy autorzy zwracają uwagę na pojęcie leśnictwa ekosystemowego w kontekście trwałej i zrównoważonej gospodarki leśnej, czyli takiego, którego podstawą sa procesy ekologiczne ${ }^{6}$, a pozyskanie drewna ma charakter drugorzędny, natomiast głównym zadaniem jest realizacja celów społecznych (walory środowiskowe i estetyczne służące rozwojowi rekreacji i turystyki, w tym zdrowotnej itp.) [Rykowski, 1998, s. 181].

Trwała i zrównoważona gospodarka leśna łączy się z koniecznością równorzędnego traktowania trzech głównych wymiarów (ładów), tj.: ekologicznego, gospodarczego i społecznego (społeczno-kulturowego). Niektórzy autorzy wyróżniają także ład instytucjonalny (instytucjonalno-prawny) [Fiedor, 2007, s. 165; Adesola, 2012, s. 13], który jednak można traktować jako element ładu społecznego [Borys, 2011, s. 77; Miś, 2015, s. 286]. Te wymiary można odnieść do różnorodnych funkcji, jakie pełnią lasy, oraz realizowanych celów (tabela 1.).

\section{Trzy wymiary zrównoważonego leśnictwa}

TABELA 1.

\begin{tabular}{|c|c|c|}
\hline Wymiar ekonomiczny & Wymiar ekologiczny & Wymiar społeczny \\
\hline \multicolumn{3}{|c|}{ Rola środowiska leśnego } \\
\hline $\begin{array}{l}\text { Lasy jako źródło drewna i innych } \\
\text { surowców (tzw. użytków ubocz- } \\
\text { nych, takich jak: zioła, grzyby, } \\
\text { owoce, zwierzyna leśna itp.). }\end{array}$ & $\begin{array}{l}\text { Lasy jako środowisko życia wie- } \\
\text { lu organizmów (złożony ekosys- } \\
\text { tem leśny, połączony zależnoś- } \\
\text { ciami z innymi ekosystemami). }\end{array}$ & $\begin{array}{l}\text { Rola środowiska leśnego w two- } \\
\text { rzeniu warunków bytowych } \\
\text { (zdrowie, jakość życia, odpoczy- } \\
\text { nek i rekreacja). }\end{array}$ \\
\hline $\begin{array}{l}\text { Lasy jako obszary wykorzysty- } \\
\text { wane przez inne branże gospo- } \\
\text { darki (głównie turystykę). }\end{array}$ & $\begin{array}{l}\text { Rola lasów w obiegu wegla i in- } \\
\text { nych pierwiastków w przyro- } \\
\text { dzie oraz w przeplywie energii. }\end{array}$ & $\begin{array}{l}\text { Estetyczna i kulturotwórcza rola } \\
\text { lasów (malarstwo, literatura, rzeź- } \\
\text { ba). }\end{array}$ \\
\hline \multicolumn{3}{|c|}{ Cele trwałej zrównoważonej gospodarki leśnej } \\
\hline $\begin{array}{l}\text { Zaspokajanie potrzeb przy wy- } \\
\text { korzystaniu produktów pocho- } \\
\text { dzących z lasów, rozwój branż } \\
\text { przemysłu związanych z lasami. }\end{array}$ & $\begin{array}{l}\text { Ciagłe odtwarzanie zasobów } \\
\text { leśnych, jak również powięk- } \\
\text { szanie ich areału poprzez zale- } \\
\text { sienia i odnowienia, poprawa } \\
\text { kondycji lasów. }\end{array}$ & $\begin{array}{l}\text { Szeroko rozumiana poprawa ja- } \\
\text { kości życia: możliwość pracy dla } \\
\text { mieszkańców danego regionu } \\
\text { i uzyskiwania dochodów z lasu, } \\
\text { co wiąże się ze zmniejszeniem } \\
\text { ubóstwa, a także powszechny } \\
\text { dostęp do lasów. }\end{array}$ \\
\hline $\begin{array}{l}\text { Zachowanie ekosystemów leś- } \\
\text { nych w dobrym stanie (ochrona } \\
\text { przed zagrożeniami naturalny- } \\
\text { mi i antropogenicznymi). }\end{array}$ & $\begin{array}{l}\text { Zachowanie najcenniejszych } \\
\text { walorów przyrodniczych } \\
\text { (ochrona przyrody). }\end{array}$ & $\begin{array}{l}\text { Zwiększenie stopnia partycypacji } \\
\text { społecznej wszystkich użytkow- } \\
\text { ników lasów (współuczestnic- } \\
\text { two w podejmowaniu decyzji). }\end{array}$ \\
\hline $\begin{array}{l}\text { Badania naukowe, monitoring } \\
\text { stanu lasów oraz pozyskiwanie, } \\
\text { zachowanie i wykorzystanie ma- } \\
\text { teriału reprodukcyjnego (nasio- } \\
\text { na, siewki) celem zwiększenia po- } \\
\text { tencjału produkcyjnego i bioróż- } \\
\text { norodności lasów. }\end{array}$ & $\begin{array}{l}\text { Zachowanie i odtwarzanie } \\
\text { bioróżnorodności lasów (eko- } \\
\text { systemów leśnych i towarzy- } \\
\text { szácych im ekosystemów nie- } \\
\text { leśnych). }\end{array}$ & $\begin{array}{l}\text { Rozwój edukacji dotyczący: roli } \\
\text { lasów, relacji ekosystemowych, } \\
\text { gospodarki leśnej, budowanie } \\
\text { świadomości ekologicznej. }\end{array}$ \\
\hline
\end{tabular}

Źródło: [Kruk, 2012, s. 139].

6 Las jest traktowany całościowo jako złożony system ekologiczny. 
Kwestie zrównoważenia gospodarki leśnej znalazły również odzwierciedlenie w polityce Unii Europejskiej. Opracowane zostały cele dla lasów europejskich (Goals for European Forests) oraz cele dla lasów w ramach strategii „Europa 2020” (European 2020 Targets for forests). W oby przypadkach podkreśla się konieczność: wprowadzania zrównoważonej gospodarki leśnej związanej z wieloma funkcjami pełnionymi przez ekosystemy leśne (w tym możliwych do uzyskania korzyści społecznych i kulturowych), dostarczania drewna i innych użytków z lasów oraz dostosowania gospodarki leśnej do zmian klimatycznych. Akcentuje się: rolę lasów w odwracaniu zjawiska pustynnienia, korzyści z wychwytywania i magazynowania węgla w biomasie leśnej czy wkład leśnictwa w rozwój tzw. zielonej gospodarki. Zwraca się także uwagę na konieczność sporządzania programów dotyczących: gospodarki leśnej, ograniczania nielegalnego pozyskiwania drewna z lasów, zmniejszania tempa utraty bioróżnorodności oraz pomiaru całkowitej wartości usług systemowych dostarczanych przez lasy [Linser, Wolfslehner, 2015, s. 9].

Trwała i zrównoważona gospodarka leśna ściśle łączy się z ekologicznymi uwarunkowaniami funkcjonowania ekosystemów leśnych, to natomiast wynika z konieczności inwentaryzacji przyrodniczej i monitorowania zmian zachodzacych w środowisku leśnym.

\section{Metody oceny trwałej i zrównoważonej gospodarki leśnej}

W literaturze przedmiotu i w praktyce gospodarczej wyodrębnia się różne systemy wskaźników odnoszących się do trwałej i zrównoważonej gospodarki leśnej. Wśród najważniejszych można wymienić:

1) ciagle rozbudowywany system mierników stworzony w ramach cyklu ministerialnych konferencji na temat ochrony lasów w Europie;

2) system wskaźników opracowany przez FAO (Organizację Narodów Zjednoczonych do spraw Wyżywienia i Rolnictwa);

3) systemy stosowane przy certyfikacji leśnej;

4) wybrane wskaźniki dotyczące gospodarki leśnej, wykorzystywane przez GUS i Eurostat do oceny zrównoważonego rozwoju Polski.

Paneuropejski system wskaźników, obejmujących zrównoważoną gospodarkę leśna, składa się z 45 mierników. Z tej grupy 34 mają charakter ilościowy (grupy wskaźników oznaczone numerami w tabeli 2.), a pozostałe 11 jakościowy (w tabeli oznaczone kursywą i symbolami z literą C). Wskaźniki stosowane zgodnie z założeniami przyjętymi podczas ministerialnych konferencji na temat ochrony lasów w Europie przedstawiono w tabeli 2 . 
TABELA 2.

Paneuropejskie wskaźniki trwałej i zrównoważonej gospodarki leśnej

\begin{tabular}{|c|c|c|}
\hline Numer & Kryteria & Wskaźniki \\
\hline $\mathrm{C}$ & $\begin{array}{l}\text { Polityka i gospodarka leśna } \\
\text { (kryteria jakościowe) }\end{array}$ & $\begin{array}{l}\text { 1. Narodowe programy gospodarki leśnej lub ich odpowiedniki } \\
\text { 2. Ramy instytucjonalne } \\
\text { 3. Ramy prawne/ regulacje (zobowiqzania na poziomie krajowym i mie- } \\
\text { dsynarodowym) } \\
\text { 4. Instrumenty finansowe i ekonomiczne } \\
\text { 5. Informacja i komunikacja }\end{array}$ \\
\hline 1 & Zasoby leśne i obieg węgla & $\begin{array}{l}\text { C1. Powiqzane polityki, instytucje oraz instrumenty } \\
\text { 1.1. Powierzchnia lasów } \\
\text { 1.2. Zasoby drzewne na pniu (miąższość drzewostanu) } \\
\text { 1.3. Struktura wiekowa lasów i (lub) rozkład grubości pierśnicy } \\
\text { drzewostanu } \\
\text { 1.4. Akumulacja węgla w lasach }\end{array}$ \\
\hline 2 & Zdrowie i żywotność lasów & $\begin{array}{l}\text { C2. Powiazane polityki, instytucje oraz instrumenty } \\
\text { 2.1. Depozycja i koncentracja zanieczyszczeń powietrza } \\
\text { 2.2. Warunki glebowe } \\
\text { 2.3. Defoliacja } \\
\text { 2.4. Uszkodzenia lasów } \\
\text { 2.5. Degradacja gruntów leśnych }\end{array}$ \\
\hline 3 & Funkcje produkcyjne & $\begin{array}{l}\text { C3. Powiazane polityki, instytucje oraz instrumenty } \\
\text { 3.1. Przyrost i pozyskanie (ścinka) drzew } \\
\text { 3.2. Drewno okragłe } \\
\text { 3.3. Użytki uboczne z lasów } \\
\text { 3.4. Usługi }\end{array}$ \\
\hline 4 & Różnorodność biologiczna & $\begin{array}{l}\text { C4. Powiazane polityki, instytucje oraz instrumenty } \\
\text { 4.1. Różnorodność gatunkowa drzew } \\
\text { 4.2. Odnowienia } \\
\text { 4.3. Naturalność } \\
\text { 4.4. Introdukowane gatunki drzew } \\
\text { 4.5. Posusz (obumarłe drzewa) } \\
\text { 4.6. Zasoby genetyczne } \\
\text { 4.7. Fragmentacja lasów } \\
\text { 4.8. Zagrożone gatunki leśne } \\
\text { 4.9. Lasy chronione } \\
\text { 4.10. Gatunki ptaków leśnych }\end{array}$ \\
\hline 5 & Funkcje ochronne & $\begin{array}{l}\text { C5. Powiqzane polityki, instytucje oraz instrumenty } \\
\text { 5.1. Lasy ochronne: glebo-, wodochronne oraz inne typy lasów } \\
\text { chroniące wybrane funkcje ekosystemów }\end{array}$ \\
\hline 6 & Kryteria społeczno-gospodarcze & $\begin{array}{l}\text { C6. Powiqzane polityki, instytucje oraz instrumenty } \\
\text { 6.1. Gospodarstwa leśne } \\
\text { 6.2. Wkład sektora leśnego do PKB } \\
\text { 6.3. Przychód netto } \\
\text { 6.4. Inwestycje w lasach i leśnictwie } \\
\text { 6.5. Siła robocza w leśnictwie } \\
\text { 6.6. Bezpieczeństwo i higiena pracy } \\
\text { 6.7. Zużycie drewna } \\
\text { 6.8. Handel drewnem } \\
\text { 6.9. Energia z biomasy drzewnej } \\
\text { 6.10. Rekreacja w lasach }\end{array}$ \\
\hline
\end{tabular}

Źródło: [The updated pan-european indicators for sustainable forest management, 2017, s. 3-4].

7 Pierśnica to obwód pnia na wysokości $1,3 \mathrm{~m}$, co zgodnie z obowiązującymi przepisami odpowiada jego średnicy. 
W powyższym systemie mierników dużą wagę przykłada się do zapewnienia trwałości produktywności lasów, jak również kwestii ochrony i zachowania ekosystemów leśnych. Początkowo brano pod uwagę mierniki stricte ilościowe, dopiero stosunkowo niedawno zaczęto uwzględniać mierniki o charakterze jakościowym [The updated paneuropean indicators for sustainable forest management, 2017, s. 2].

Wskaźniki zrównoważonej gospodarki leśnej, według metodyki FAO, zostały podzielone na siedem głównych obszarów tematycznych, takich, jak:

- powierzchnia i charakterystyka lasów - dotyczy lasów oraz innych zadrzewionych obszarów nieleśnych itp.;

- produkcja leśna - przyrost zasobów drzewnych, skład gatunkowy lasów, pozyskanie drewna i produktów niedrzewnych, węgiel związany w lasach itp.;

- funkcje ochronne i wybrane usługi ekosystemowe - lasy ochronne i dostarczające usługi ekosystemowe;

- zachowanie bioróżnorodności i ochrona przyrody - obszary chronione (parki narodowe, krajobrazowe, rezerwaty przyrody, obszary chronionego krajobrazu, obszary sieci „Natura 2000” itp.) na terenach leśnych;

- zakłócenia i degradacja lasów - szkody spowodowane przez gatunki inwazyjne (owady i grzyby), pożary w lasach;

- pomiar postępu we wdrażaniu założeń zrównoważonej gospodarki leśnej - ramy prawne, monitoring efektów prowadzonej polityki, udział interesariuszy w podejmowaniu decyzji, certyfikacja leśna itp.;

- ekonomika leśnictwa i środki utrzymania - wydatki na: leśnictwo, zatrudnienie w lasach, udział leśnictwa w PKB Jabłoński i in. 2013, s. 6-28; Global forest resources assessment 2015, 2015, s. v-vii].

W każdym z tych obszarów jest badana wartość poszczególnych wskaźników w ujęciu bezwzględnym oraz jego zmiany w czasie od 1990 roku Jabłoński i in. 2013, s. 6-28; Global forest resources assessment 2015, 2015, s. v-vii].

Kwestie związane z: ochroną środowiska leśnego, zachowaniem bioróżnorodności oraz rozwojem społeczno-gospodarczym zostały również uwzględnione w dwóch powszechnie stosowanych systemach certyfikacji leśnej, takich jak FSC (Forest Stewardship Council) oraz PEFC (Programme for the Endorsement of Forest Certification Schemes). Wskaźniki (głównie o charakterze jakościowym, związane z metodą FSC obejmującą ocenę dobrej gospodarki leśnej), zostały przypisane do dziesięciu głównych zasad. Są to następujące zasady:

- $\quad$ przestrzeganie przepisów prawnych i zasad FSC;

- odpowiedzialność wynikająca z tytułów własności i praw;

- prawa ludności rdzennej;

- $\quad$ współpraca ze społeczeństwem i prawa pracowników;

- $\quad$ korzyści z lasu;

- oddziaływanie na środowisko;

- plan urządzenia;

- monitorowanie i ocena;

- zachowanie lasów o szczególnej wartości; 
- plantacje [Krajony standard gospodarki leśsej FSC w Polsce, 2013, s. 2].

Ocena w tym systemie jest prowadzona na podstawie: analizy dokumentacji, map, wywiadów z różnymi grupami interesariuszy (pracownikami, społecznościami lokalnymi, zarządzającymi itp.) oraz wizyt terenowych [Krajony standard gospodarki leśnej FSC w Polsce, 2013, s. 12-39].

Natomiast w systemie PEFC wskaźniki (jakościowe i ilościowe) zostały przyporządkowane do siedmiu podstawowych kryteriów, tj.:

1. zachowanie $i$ wtaścine wrmacnianie zasobón lésnych $i$ ich udziat w globalnym obiegu wegla;

2. utraymanie zdrowia $i$ synotności ekosystemu lesnego;

3. zachowanie $i$ wrmacnianie produk.cyjnych funk cii lasów (produk.ty drzewne i niedrzewne);

4. zachowanie, ochrona i wtaściwe wrmacnianie różnorodności biologicznej ekosystemów leśnych;

5. Zachowanie, ochrona $i$ wtaścine wrmacnianie funkegi ochronnych w gospodarce leśnej (zw taszcra gleby $i$ wody);

6. zachowanie innych funkcii $i$ warunków spoteczno-ekonomicznych;

7. zgodność z uymogami prawnymi [Zrónnowažona gospodarka lésna - mymagania, 2012, s. 2].

W tym systemie certyfikacji są stosowane wskániki ilościowe (np.: zmiany powierzchni lasów, powierzchnia drzewostanów uszkodzonych przez zwierzynę, owady czy grzyby, udział wartości sprzedanych niedrzewnych użytków w przychodach ogółem, zmiany powierzchni obszarów chronionych, udział lasów ochronnych w powierzchni lasów ogółem itp.) oraz jakościowe (np.: dostępność planów urządzenia lasów, prowadzenie monitoringu lasów, współpracy z różnymi instytucjami, możliwość zgłaszania skarg i wniosków itd.) [Zrównoważona gospodarka leśna - mymagania, 2012, s. 8-22]. Można również dostrzec zbieżność między miernikami stosowanymi w systemie PEFC a paneuropejskim systemem wskaźników.

Problematyka gospodarki leśnej jest również uwzględniana w zestawach wskaźników zrównoważonego rozwoju opracowanych przez GUS i Eurostat. W przypadku metodyki Eurostatu w ósmym obszarze tematycznym (zasoby naturalne), w grupie mierników dotyczących bioróżnorodności, wskazano jako jedyny w tym zakresie wskaźnik objaśniający posusz (obumarłe drzewa) w lasach, natomiast wśród mierników dotyczących użytkowania gruntów jako jeden z dwóch wskaźników operacyjnych wymieniono przyrost i pozyskanie drzew [http://ec.europa.eu/eurostat/web/sdi/ indicators/natural-resources]. Z kolei, system wskaźników do oceny zrównoważonego rozwoju stosowany przez GUS można podzielić na trzy poziomy, tj.: krajowy, regionalny i lokalny. Zestawienie mierników obejmujące lasy i gospodarkę leśną przedstawiono w tabeli 3 .

Dobór wskaźników w poszczególnych modułach jest związany z odmiennymi kryteriami i celami oceny trwałej i zrównoważonej gospodarki leśnej na różnych szczeblach. Na poziomie poszczególnych jednostek prowadzących gospodarkę leśną wskaźniki są tak dobierane, aby umożliwiały ocenę prowadzonej gospodarki i doprecyzowywały kwestie związane z certyfikacją leśna. $\mathrm{Na}$ wyższych poziomach (skala regionalna i krajowa) celem stosowania wskaźników jest monitorowanie zachodzących zmian (ich tempa i kierunku), ocena poziomu zrównoważenia gospodarki leśnej, głównych zagrożeń i słabych stron oraz pomoc w ocenie stopnia realizacji programów, 
strategii i polityki leśnej czy też w opracowaniu nowych. Natomiast na poziomie międzynarodowym stosowanie mierników pozwala na upowszechnienie wiedzy o założeniach trwałej i zrównoważonej gospodarce leśnej, dostarcza danych do porównań międzynarodowych, a także stanowi podstawę prowadzenia negocjacji, przygotowywania krajowych programów i strategii [Baycheva i in., 2013, s. 18].

TABELA 3.

Wskaźniki dotyczące bezpośrednio gospodarki leśnej w systemie wskaźników zrównoważonego rozwoju GUS

\begin{tabular}{|l|c|c|c|}
\hline $\begin{array}{c}\text { Lad / obszar tema- } \\
\text { tyczny }\end{array}$ & Moduł krajowy & Moduł regionalny & Moduł lokalny \\
\hline $\begin{array}{l}\text { Lad środowiskowy / } \\
\text { użytkowanie grun- } \\
\text { tów }\end{array}$ & $\bullet$ lesistość & $\begin{array}{l}\text { - lesistość } \\
\text { udział powierzchni od- } \\
\text { nowień i zalesień w po- } \\
\text { wierzchni lasów ogó- } \\
\text { tem }\end{array}$ & $\begin{array}{l}\text { ・ lesistość } \\
\text { intensywność zale- } \\
\text { sień }\end{array}$ \\
\hline $\begin{array}{l}\text { Lad środowiskowy / } \\
\text { bioróżnorodność }\end{array}$ & $\begin{array}{l}\text { - uszkodzenia } \\
\text { drzew (defolia- } \\
\text { cja) }\end{array}$ & - & - \\
\hline $\begin{array}{l}\text { Lad gospodarczy / } \\
\text { rozwój gospodarczy }\end{array}$ & - & $\begin{array}{l}\text { - udział wartości dodanej } \\
\text { brutto, według PKD } \\
\text { leśnictwo łacznie z rol- } \\
\text { nictwem, łowiectwem } \\
\text { i rybactwem) }\end{array}$ & \\
\hline
\end{tabular}

Źródło: [http://wskaznikizrp.stat.gov.pl/index.jsf?jezyk=pl].

Poza wymienionymi systemami mierników są także inne autorskie metody pomiaru, które zazwyczaj dotyczą wybranych zagadnień lasów i zagospodarowania. Można tutaj wymienić systemy mierników do oceny bioróżnorodności lasów, które na ogół są stosowane w aspekcie trwałej i zrównoważonej gospodarki leśnej [por. np.: Noss, 1999, s. 142-143; Hagan, Whitman, 2006, s. 205; Barbati i in. 2014, s. 150-152; Tolunay, Akyol, 2015, s. 160-163]. Ponadto, warto zauważyć, że w leśnictwie od dawna są wykorzystywane metody i techniki oceny obejmujące zagospodarowanie lasu dla różnych celów niezwiązanych bezpośrednio z funkcja produkcyjna, w tym m.in. do: wyodrębniania funkcyjnych typów lasu, waloryzacji rekreacyjnej lasów, oceny obciążenia rekreacyjnego, oceny krajobrazu leśnego itp., jak również waloryzację lasów wielofunkcyjnych [por. np.: Ważyński, 1997, s. 31, 37-42, 48-60, 83-98; Gołojuch, Pokora, 2008, s. 220-222].

Do najczęściej stosowanych wskaźników gospodarki leśnej można zaliczyć: ogólny poziom lesistości; wielkość: zalesień, odnowień i pozyskania drewna; obszary chronione w lasach i powierzchnię lasów ochronnych; pozyskiwanie produktów niedrzewnych (użytki uboczne z lasów); posusz w lasach; defoliację i inne uszkodzenia drzew. 


\section{Zmiany poziomu zrównoważenia gospodarki leśnej w Polsce - wybrane parametry}

Warto dokonać oceny zmian w poziomie zrównoważenia gospodarki leśnej w Polsce na podstawie wybranych wskaźników. Do analizy wybrano zarówno wskaźniki podstawowe, jak i inne, typowe dla Polski, np. liczbę leśnych kompleksów produkcyjnych (tabela 4.).

TABELA 4.

Wybrane wskaźniki zrównoważenia gospodarki leśnej w Polsce

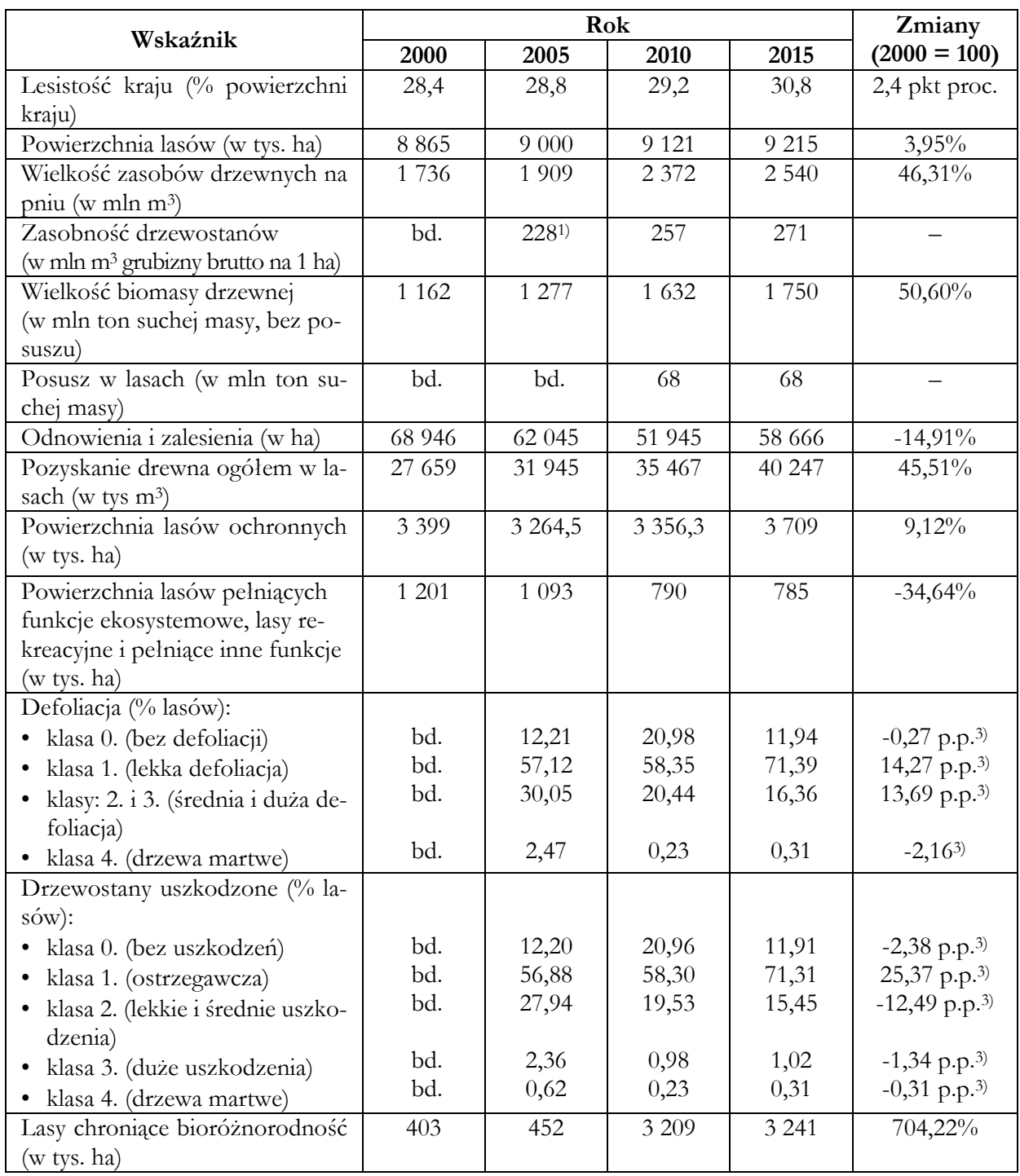




\begin{tabular}{|c|c|c|c|c|c|}
\hline \multirow{2}{*}{ Wskaźnik } & \multicolumn{4}{|c|}{ Rok } & \multirow{2}{*}{$\begin{array}{c}\text { Zmiany } \\
(2000=100)\end{array}$} \\
\hline & 2000 & 2005 & 2010 & 2015 & \\
\hline $\begin{array}{l}\text { Lasy w granicach rezerwatów } \\
\text { przyrody i parków narodowych } \\
\text { (w tys. ha) }\end{array}$ & 180 & 183 & 184 & 184 & $2,22 \%$ \\
\hline $\begin{array}{l}\text { Certyfikacja leśna (powierzchnia } \\
\text { lasów objętych certyfikatami w tys. } \\
\text { ha) } \\
\text { - FSC } \\
\text { - PEFC }\end{array}$ & $\begin{array}{l}0 \\
0\end{array}$ & $\begin{array}{c}6977,56 \\
0\end{array}$ & $\begin{array}{c}6387,11 \\
317,29\end{array}$ & $\begin{array}{c}\left.6920^{2}\right) \\
7277,70\end{array}$ & - \\
\hline $\begin{array}{l}\text { Wartość skupu owoców i grzy- } \\
\text { bów leśnych (w tys. zł) }\end{array}$ & 71754,9 & 132720,3 & 110869,1 & 87732,7 & $22,27 \%$ \\
\hline $\begin{array}{l}\text { Wartość skupu zwierzyny łownej } \\
\text { (w tys. zł) }\end{array}$ & bd. & bd. & 63435,9 & 98 192,7 & - \\
\hline $\begin{array}{l}\text { Wartość dodana brutto leśnictwa } \\
\text { (w mln zł) }\end{array}$ & bd. & 2677,9 & 4155,0 & 5832,5 & $117,8 \% 0^{3)}$ \\
\hline $\begin{array}{l}\text { Leśne Kompleksy Promocyjne } \\
\text { (liczba) }\end{array}$ & 10 & 19 & 19 & 25 & $150 \%$ \\
\hline
\end{tabular}

bd. - brak danych

1) tylko dla lasów w zarządzie Lasów Państwowych

2) dane dla roku 2014

3) zmiany w stosunku do roku 2005

Źródło: opracowanie własne na podstawie: [Lénictwo 2006, 2006 s. 27, 34, 37, 47, 77, 83, 90, 176; Leśnictwo 2011, 2011, s. 29, 38, 40, 111, 121-122; Leśnictwo 2016, 2016, s. 37, 118, 126, 127 , 156, 178, 236, 325-327; Jabłoński i in. 2013, s. 13, 15, 24; FRA 2015 - Country Report: Poland, 2014, s. 27, 44, 50, 73; PEFC Annual Review 2015, 2016, s. 20].

Poziom lesistości kraju zwiększa się mimo rosnącego pozyskania drewna. Powoduje to jednak pewne zmiany w strukturze wiekowej lasów, choć przeciętny wiek drzewostanu w latach zmienia się w minimalnym stopniu. Zmienia się także skład gatunkowy lasów: udział drzew iglastych jest stopniowo ograniczany ${ }^{8}$, natomiast zwiększa się powierzchnia, na której rosną drzewa liściaste [Leśnictwo 2006, 2006, s. 37, 40, 289; Leśnictwo 2011, 2011, s. 38, 45, 56; Lésnictwo 2016, 2016, s. 45-47, 336, 338]. W badanym okresie tempo odnowień i zalesień było wolniejsze. Jest to tłumaczone zmianą kryteriów branych pod uwagę przy zalesianiu gruntów rolnych oraz zmianą polityki Agencji Polityki Rolnej, która ograniczyła przekazywanie gruntów pod zalesienia Lasów Państwowych [Raport o stanie lasów w Polsce 2015, 2016, s. 19]. Pewną niepokojąca tendencja jest więc spadek powierzchni odnowień lasów i zalesianych nowych obszarów w połączeniu z rosnącym tempem pozyskiwania drewna. Mimo rosnącego pozyskania, wielkość zasobów drzewnych na pniu oraz zasobność drzewostanów ulega zwiększe-

8 Drewno iglaste, szczególnie sosnowe, było preferowane przez przemysł drzewny, stąd też w poprzednich dziesięcioleciach drzewa były sadzone również na siedliskach typowych dla drzew liściastych [np. Raport o stanie lasów w Polsce 2010, 2011, s. 13]. 
niu. Lesistość w Polsce zwiększa się, choć jest ciagle niższa niż średnia dla Unii Europejskiej [Agriculture, forestry and fishery statistics, 2016 s. 166; Leśnictwo 2016, 2016, s. 291; Raport o stanie lasów w Polsce 2015, 2016, s. 10].

Analizując zmiany zachodzące w czasie, warto zauważyć bardzo duże zwiększenie powierzchni lasów chroniących bioróżnorodność (według metodyki FAO), co wiąże się z wprowadzeniem sieci „Natura 2000”, oraz wzrost powierzchni lasów ochronnych i lasów objętych certyfikacją leśną. W niewielkim stopniu zmieniła się powierzchnia parków narodowych i rezerwatów przyrody w lasach. Natomiast zmalała powierzchnia lasów pełniących funkcje ekosystemowe $\mathrm{i}$ inne funkcje (lasy przeznaczone do masowego wypoczynku i rekreacji, wiązania węgla, o wartościach kulturowych i religijnych, obronne itd.).

Warto również odnotować zmniejszenie się, w sposób znaczący, powierzchni lasów uszkodzonych i dotkniętych defoliacją, co może świadczyć o właściwie prowadzonej gospodarce leśnej, w tym przebudowie drzewostanów. Konstatując, można przyjać, iż założenia rozwoju zrównoważonego były i są wprowadzane do gospodarki leśnej, a ich skutkiem jest między innymi zwiększenie powierzchni lasów i poprawa ich stanu zdrowotnego.

Kolejną kwestia jest wykorzystanie zasobów niedrzewnych w lasach. Dane statystyczne dotyczące: pozyskania zwierzyny, owoców runa czy ziół są dość ogólne. Jednak jest widoczny wzrost wartości wykorzystywanych tego typu zasobów leśnych. Pozyskiwanie owoców leśnych, grzybów i ziól, a także zwierzyny łownej jest zgodne z założeniami wielofunkcyjnej gospodarki leśnej. Generalnie, można zaobserwować wzrost wartości dodanej brutto leśnictwa.

Powoływane są nowe, leśne kompleksy promocyjne (LKP) ${ }^{9}$, czyli lasy o wysokich walorach przyrodniczych, pełniące znaczącą funkcję ekologiczną i społeczną. Na terenie LKP edukacja leśna jest prowadzona szczególnie intensywnie [Raport o stanie lasón w Polsce 2015, 2016, s. 35]. Istotnie zwiększa się zarazem liczba osób korzystających z edukacji leśnej: z około 1,8 mln w 2010 roku do ponad 3,5 mln w roku 2015. Wykorzystanie edukacyjne, turystyczne i rekreacyjne lasów wiąże się z rozbudową odpowiedniej infrastruktury (szlaki turystyczne, miejsca biwakowania i odpoczynku, pozostałe obiekty edukacyjne i turystyczne itp.) [Raport o stanie lasów w Polsce 2010, 2011, s. 31-33; Raport o stanie lasów w Polsce 2015, 2016, s. 34-37].

\section{Podsumowanie}

Aby zbadać skuteczność prowadzonej gospodarki leśnej oraz postęp we wdrażaniu celów i zasad rozwoju zrównoważonego, w leśnictwie stosuje się różne systemy mierników opracowywane na poziomie krajowym i międzynarodowym (Europa) lub nawet globalnym (FAO). Wykorzystywane mierniki pozwalają na dokładną charakterystykę $i$ analizę zmian zachodzacych w czasie (w odniesieniu do wymiaru ekologicznego (w tym zachowania bioróżnorodności) i gospodarczego. Jednak można stwierdzić pewne niedostatki w systemie mierników dotyczących wymiaru społecznego, który, w porównaniu

9 To polska koncepcja, która ma niewiele swoich odpowiedników w świecie. 
z dwoma poprzednimi grupami wskaźników, jest słabo rozbudowany. Obecnie stosowany system gromadzenia danych również nie zawsze dostarcza informacji niezbędnych do dokonywania porównań międzynarodowych, szczególnie w przypadku metody oceny stosowanej przez FAO.

Analizując wybrane dane statystyczne z lat 2000-2015, można skonstatować, iż poprawia się poziom zrównoważenia gospodarki leśnej w Polsce. Zwiększa się lesistość, zmniejsza odsetek lasów uszkodzonych w wyniku różnego rodzaju zakłóceń i zanieczyszczeń, funkcje produkcyjne i ochronne lasów są dobrze zrównoważone, a działania w zakresie zachowania bioróżnorodności są skuteczne. Można przypuszczać iż duży udział lasów publicznych ${ }^{10}$, w tym tych będących w administracji PGL Lasy Państwowe, warunkuje prowadzenie spójnej i trwałej gospodarki leśnej.

\section{Literatura}

Adesola S.A., 2012, Overcoming the challanges of sustainable development through science and technology education, "Journal of Educational and Social Research", vol. 2 (7), DOI: 10.5901/jesr.2012.v2n7p11.

Agriculture, forestry and fishery statistics, 2016, Statistical Books, Eurostat, European Union, DOI: $10.2785 / 917017$.

Barbati A. i in., 2014, European forest types and Forest Europe FSM indicators: tool for monitoring progress on forest biodiverssity conservation, "Forest Ecology and Management", vol. 321, DOI: http://dx.doi.org/10.1016/ j.foreco.2013.07.004.

Baycheva T. i in., 2013, Implementing criteria and indicatorsfor sustainable forest management in Europe, Europa Forest Institute.

Borys T., 2011, Zrównoważony rozwój- jak rozpoz̨nać ład qintegrowany, „Problemy Ekorozwoju - Problems of Sustainable Development”, vol. 6, no. 2.

Chmielewski J., 2015, Zasady ogólne gospodarki leśnej i prawa lésnego, „Krytyka Prawa”, t. 7 (1), DOI: 10.7206/kp.2080-1084.76.

Fiedor B., 2007, Nowa ekonomia instytucjonalna a zrónnoważony rozwój, [w:] Obszary badań nad trwałym $i$ zrónnoważonym roswojem, B. Poskrobko (red.), Wydawnictwo „Ekonomia i Środowisko", Białystok.

FRA 2015 (Global Forest Resources Assessment 2015) - Country Report: Poland, 2014, FAO, Rzym, http://www.fao.org/3/a-i4808e.pdf (data wejścia: 11.05.2017).

Global forest resources assessment 2015, 2015, Food and Agriculture Organization of the United States, Rzym, http://www.fao.org/documents/card/en/c/bcfc625a-273a4aa3-acc3-4c18ada7b950/(data wejścia: 30.05.2017).

Gołojuch P., Pokora, J., 2008, Zróżnicowanie funkeji lasu dla wybranych cech taksacyjnych drzęwostanów, „Studia i Materiały Centrum Edukacji Przyrodniczo-Leśnej”, z. 3(19).

Hagan J.M., Whitman A.A., 2006, Biodiversity indicators for sustainable forestry: simplifying complexity, "Journal of Forestry", vol. 104.

10 W 2015 roku 80,8\% lasów w Polsce stanowiły lasy publiczne [por. Leśnictwo 2016, 2016, s. 37]. 
http:/ / ec.europa.eu/eurostat/web/sdi/indicators/natural-resources (data wejścia: 01.06.2017).

http://wskaznikizrp.stat.gov.pl/index.jsf?jezyk=pl (data wejścia: 01.06.2017).

Jabłoński M. i in., 2013, Ocena stanu i zmian zasobów leśnych Polski wedtug kryteriów i wskaźników opracowanych prez. UNECE, FAO oraz FOREST EUROPE na potrzeby raportowania. Etap I, Instytut Badawczy Leśnictwa, Zakład Zarządzania Zasobami Leśnymi, Sękocin Stary.

Kant S., Berry R.A., 2005, Economics, sustainability and forest management, [in:] Economics, sustainability and natural resources, S. Kant, R.A. Berry (eds.), vol. 1, Springer, Netherlands.

Krajowy standard gospodarki leśnej FSC w Polsce (FSC-STD-POL-01-01-2013), 2013, FSC Polska, Zielona Góra, http://www.lasy.gov.pl/nasza-praca/certyfikacja/fsc-stdpol-01-01-2013-pl.pdf (data wejścia: 20.05.2017).

Kruk H., 2012, Zrównoważone leśnictwo w Polsce, [w:] Trendy i wyžwania zrównoważonego rozwoju w XXI wieku, B. Kryk (red.), „Handel Wewnętrzny”, t. 1, lipiec-sierpień.

Leśnictwo 2006, 2006, Informacje i opracowania statystyczne, Główny Urząd Statystyczny, Warszawa.

Leśnictwo 2011, 2011, Informacje i opracowania statystyczne, Główny Urząd Statystyczny, Warszawa.

Leśnictwo 2016, 2016, Informacje i opracowania statystyczne, Główny Urząd Statystyczny, Warszawa.

Linser S., Wolfslehner B., 2015, Meeting the goals for European forests and the European 2020 targets for forests, European Forest Institute / EFICEEC-EFISEE, Wiedeń.

Miś T., 2015, Rola kapitału społecznego w zrównoważonym rozwoju obszarów wiejskich, „Nierówności Społeczne a Wzrost Gospodarczy”, nr 42.

Noss R.F., 1999, Assessing and monitoring forest biodiversity: a suggested framework and indicators, „Forest Ecology and Management”, vol. 115.

Opinia Europejskiego Komitetu Ekonomiczno-Społecznego w sprawie komunikatu Komisji do Parlamentu Europejskiego, Rady, Europejskiego Komitetu Ekonomiczno-Spolecznego i Komitetu Regionów „Nowa strategia leśna UE na rzecz lasów i sektora leśno-drzewnego”, COM(2013) 659 final, Dz. U. UE C 451/127 z 16.12.2014, http:/ / eur-lex.europa.eu/ legal-content/PL/TXT/?uri=CELEX\%3A52013DC0659 (data wejścia: 11.05.2017).

Paschalis-Jakubowicz P., 2011, Teoretyczne podstawy i realizacja idei zrównoważonego rozwoju w leśnictwie, „Problemy Ekorozwoju - Problems of Sustainable Development”, vol. 6, no. 2.

PEFC Annual Review 2015, 2016, PEFC, http://pefc.org/images/documents/annual_ review/PEFC_2015_annual_review.pdf (data wejścia: 01.06.2017).

Płotkowski L., 2010, Gospodarka leśna w badaniach ekonomiki leśnictwa, „Roczniki Nauk Rolniczych", seria G, t. 92, z. 2.

Polityka leśna państwa, 1997, Ministerstwo Ochrony Środowiska, Zasobów Naturalnych i Leśnictwa, Warszawa.

Raport o stanie lasów w Polsce 2010, 2011, PGL LP, Generalna Dyrekcja Lasów Państwowych, Warszawa, http://www.lasy.gov.pl/informacje/publikacje/informacje-statystyczne-i-raporty/raport-o-stanie-lasow (data wejścia: 01.06.2017). 
Raport o stanie lasów w Polsce 2015, 2016, PGL LP, Generalna Dyrekcja Lasów Państwowych, Warszawa, http://www.lasy.gov.pl/informacje/publikacje/informacje-statystyczne-i-raporty/raport-o-stanie-lasow (data wejścia: 01.06.2017).

Report of the United Nations conference on environment and development. Annex III: Non-legally binding authoritative statement of principles for a global consensus on the management, conservation and sustainable development of all types of forests, A/CONF.151/26 (vol. III), http://www.un.org/documents/ga/conf151/aconf15126-3annex3.htm (data wejścia: 30.05.2017).

Rykowski K., 1998, Trwaly i zrównoważony rozwój lasów - zarys problematyki, [w:] Trwaly $i$ zrównoważony rozwój lasów. Poglady - opinie - kontrowersje, K. Rykowski (red.), Instytut Badawczy Leśnictwa, Warszawa.

The updated pan-european indicators for sustainable forest management, 2017, http://foresteurope.org/wp-content/uploads/2017/05/CI_4pages_Com.pdf (data wejścia: 30.05.2017).

Tolunay A., Akyol A., 2015, Identification of appropriate biodiversity indicators for ecologically sustainable forest management at nationale level, "SainsMalaysiana", vol. 44(2).

UN Strategic plan for forests, 2017-2030, http://www.un.org/esa/forests/wp-content/uploads/2016/12/UNSPF_AdvUnedited.pdf (data wejścia: 11.05.2017).

Ustawa z. dnia 28 września 1991 roku - Ustawa o lasach, Dz. U., 1991, Nr 101, poz. 444 z pózn. zm., tekst ujednolicony, isap.sejm.gov.pl (data wejścia: 21.03.2017).

Ważyński B., 1997, Urzadzanie i zagospodarowanie lasu dla potrzeb turystyki i rekreacji, Wydawnictwo Akademii Rolniczej im. A. Cieszkowskiego w Poznaniu, Poznań.

Zasady hodowli lasu, 2012, Centrum Informacyjne Lasów Państwowych, Warszawa, http://www.lasy.gov.pl/publikacje/copy_of_gospodarka-lesna/hodowla/zasadyhodowli-lasu-dokument-w-opracowaniu (data wejścia: 11.05.2017).

Zrównoważona gospodarka leśna - wymagania, norma krajowa PEFC PL 1003:2012, 2012, http://www.pefc.pl/images/PEFC_PL_1003v.2-pol_final.pdf (data wejścia: 11.05.2017). 